Louisiana State University

LSU Digital Commons

$6-1-2004$

\title{
Universal primers for the amplification of chloroplast microsatellites in grasses (Poaceae)
}

Jim Provan

Queen's University Belfast

Pamela M. Biss

The Open University

Darragh McMeel

Queen's University Belfast

Sarah Mathews

University of Missouri

Follow this and additional works at: https://digitalcommons.Isu.edu/biosci_pubs

\section{Recommended Citation}

Provan, J., Biss, P., McMeel, D., \& Mathews, S. (2004). Universal primers for the amplification of chloroplast microsatellites in grasses (Poaceae). Molecular Ecology Notes, 4 (2), 262-264.

https://doi.org/10.1111/j.1471-8286.2004.00636.x

This Article is brought to you for free and open access by the Department of Biological Sciences at LSU Digital Commons. It has been accepted for inclusion in Faculty Publications by an authorized administrator of LSU Digital Commons. For more information, please contact ir@lsu.edu. 


\title{
PRIMER NOTE
}

\section{Universal primers for the amplification of chloroplast microsatellites in grasses (Poaceae)}

\author{
JIM PROVAN,*PAMELA M. BISS,+ DARRAGH McMEEL*and SARAH MATHEWS $\$ \S$ \\ *School of Biology and Biochemistry, The Queen's University of Belfast, 97 Lisburn Road, Belfast BT9 7BL, Northern Ireland, \\ †Department of Biological Sciences, The Open University, Walton Hall, Milton Keynes, Bucks MK7 6AA, UK, ‡Division of Biological \\ Sciences, University of Missouri - Columbia, 226 Tucker Hall, Columbia, MO 65211, USA
}

\begin{abstract}
Attempts to design truly universal primers to amplify chloroplast microsatellites have met with limited success due to nonconservation of repeat loci across widely divergent taxa. We have used the complete chloroplast genome sequences of rice, maize and wheat to design five pairs of primers that amplify homologous mononucleotide repeats across the Poaceae (grasses). Sequencing confirmed conservation of repeat motifs across subfamilies and a preliminary study in Anthoxanthum odoratum revealed polymorphism at two loci with a haplotype diversity value of $\mathbf{0 . 4 9 5}$. These primers provide a valuable tool to study cytoplasmic diversity in this extensively studied and economically important range of taxa.
\end{abstract}

Keywords: chloroplast, grasses, microsatellite, Poaceae, simple sequence repeat, universal primers

Received 24 September 2003; revision accepted 4 February 2004

Chloroplast microsatellites [cp simple sequence repeats (SSRs)] are now becoming firmly established as a highresolution tool for examining levels and patterns of cytoplasmic variation in a wide range of plant species (for review see Provan et al. 2001). Despite their value, their utility has been limited somewhat by the requirement for chloroplast sequence information to identify cpSSRs and to design primers to the regions flanking the repeats to facilitate polymerase chain reaction (PCR) amplification. Previous attempts at designing universal cpSSR primers have met with limited success (e.g. Weising \& Gardner 1999), generally due to the lack of conservation of homologous mononucleotide repeat motifs at higher taxonomic levels. Between genera within a family, however, levels of conservation of chloroplast microsatellites are usually fairly high (Provan et al. 1999, 2001) and, on this basis, we have designed five pairs of primers to amplify cpSSRs across the Poaceae.

The Poaceae (grasses) represent probably the single most important family of plants in the world, both economically and ecologically. There are around 650 genera and almost 10000 species of grasses and they exhibit an

Correspondence: Dr Jim Provan. Fax: + 44289033 5877; E-mail: J.Provan@qub.ac.uk.

§Present address: Arnold Arboretum of Harvard University, 22 Divinity Avenue, Cambridge, MA 02138, USA. almost ubiquitous ecological distribution, being absent only from the highest altitudes and polar regions. Cereals such as maize, wheat and rice represent the main food source for the vast majority of the world's population and, in addition, forage and turf grasses are also of great agronomic importance. Thus, these primers represent a novel tool for cytoplasmic analysis in an extremely broad and important range of taxa.

The complete chloroplast genome sequences of Oryza sativa (rice), Zea mays (maize) and Triticum aestivum (wheat) were searched for all mononucleotide repeats of eight bases or more using the FINDPATTERNS program (Genetics Computer Group). Five homologous cpSSRs in noncoding regions were conserved across all three species and these repeats plus their flanking regions were aligned using the PILEUP program (Genetics Computer Group). Primers were then designed manually to amplify each repeat and are given in Table 1 (GenBank Accession nos XXXXX-XXXXX).

The PCRs were carried out on the following species belonging to the Poaceae (subfamily in brackets): Aristida longiseta (Arundinoideae), Bouteloua gracilis (Chloridoideae), B. hirsute (Chloridoideae), Chasmanthium latifolium (Centothecoideae), Danthonia spicata (Arundinoideae), Deschampsia flexuosa (Pooideae), Ehrharta erecta (Bambusoideae), Hordeum spontaneum (Pooideae), Lolium perenne (Pooideae), Molinia caerulea (Arundinoideae), Sorghum 
Table 1 Poaceae universal chloroplast microsatellite primers

\begin{tabular}{|c|c|c|c|c|c|c|}
\hline \multirow[b]{2}{*}{ Locus } & \multirow[b]{2}{*}{ Primers } & \multirow[b]{2}{*}{$T_{\mathrm{m}}\left({ }^{\circ} \mathrm{C}\right)$} & \multirow[b]{2}{*}{ Size $(b p)^{*}$} & \multicolumn{3}{|c|}{ Length of mononucleotide repeat +} \\
\hline & & & & Oryza & Triticum & Zea \\
\hline $\operatorname{trn} \mathrm{K}$ intron & $\begin{array}{l}\text { ATACAGTCTCTTTATCAATATACTG } \\
\text { GACGTTAAAAATAGATTAGTGCC }\end{array}$ & 58 & 172 & $(\mathrm{~A})_{10} \mathrm{G}(\mathrm{A})_{6}$ & $(\mathrm{~A})_{10} \mathrm{G}(\mathrm{A})_{6}$ & $(\mathrm{~A})_{11}$ \\
\hline$p s b \mathrm{~K} / p s b \mathrm{I}$ & $\begin{array}{l}\text { GGAAAAAYKGGTAATCTATTCC } \\
\text { GAAACAAAGAATATCACTACTG }\end{array}$ & 56 & 101 & $(\mathrm{~A})_{9}$ & $(\mathrm{~A})_{9}$ & $(\mathrm{~A})_{8}$ \\
\hline rpoC2/rps2 & $\begin{array}{l}\text { TTATTTATTTCAAGCTATTTCGG } \\
\text { AATATCTTCTTGTCATTTTTTCC }\end{array}$ & 56 & 127 & $(\mathrm{~A})_{8} \mathrm{G}(\mathrm{A})_{6}$ & $(\mathrm{~A})_{9}$ & $(\mathrm{~A})_{9} \mathrm{G}(\mathrm{A})_{6}$ \\
\hline $\operatorname{atp} \mathrm{I} / \operatorname{at} p \mathrm{H}$ & $\begin{array}{l}\text { TGGTTGATTGTATCCTTAACC } \\
\text { GAAGCAGCAGCAATTAGTGG }\end{array}$ & 56 & 77 & $(\mathrm{~T})_{8}$ & $(\mathrm{~T})_{8}$ & $(\mathrm{~T})_{9}$ \\
\hline$a t p \mathrm{~B} / r b c \mathrm{~L}$ & $\begin{array}{l}\text { GATTGGTTCTCATAATTATCAC } \\
\text { TATTGAATTAACTAATTCATTTCC }\end{array}$ & 56 & 149 & $(\mathrm{~T})_{7}$ and $(\mathrm{A})_{8}$ & $(\mathrm{~T})_{7}$ and $(\mathrm{A})_{8}$ & $(\mathrm{~T})_{8}$ and $(\mathrm{A})_{10}$ \\
\hline
\end{tabular}

*Expected size in Oryza.

+Homologous repeats found in EMBL database sequences for complete chloroplast genomes.

$T_{\mathrm{m}^{\prime}}$ annealing temperature.

Table 2 Conservation of mononucleotide repeats across taxa studied

\begin{tabular}{|c|c|c|c|c|c|}
\hline \multirow[b]{2}{*}{ Species } & \multicolumn{5}{|c|}{ Mononucleotide motif } \\
\hline & 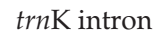 & $r p o \mathrm{C} 2 / r p s 2$ & $\operatorname{atpI} / \operatorname{atp} \mathrm{H}$ & $a t p \mathrm{~B} / r b c \mathrm{~L}$ & $p s b \mathrm{~K} / p s b \mathrm{I}$ \\
\hline Bouteloua gracilis & $(\mathrm{A})_{8} \mathrm{G}(\mathrm{A})_{6}$ & $(\mathrm{~A})_{11}$ & $(\mathrm{~T})_{8}$ & $(\mathrm{~T})_{9}$ & $(\mathrm{~A})_{11}$ \\
\hline Chasmanthium latifolium & $(\mathrm{A})_{8} \mathrm{G}(\mathrm{A})_{6}$ & $(\mathrm{~A})_{8} \mathrm{G}(\mathrm{A})_{6}$ & $(\mathrm{~T})_{9}^{0}$ & $(\mathrm{~T})_{7}$ and $(\mathrm{A})_{10}$ & $(\mathrm{~A})_{9}$ \\
\hline Danthonia spicata & $(\mathrm{A})_{9} \mathrm{G}(\mathrm{A})_{6}$ & $(\mathrm{~A})_{6} \mathrm{G}(\mathrm{A})_{6}$ & $(\mathrm{~T})_{9}$ & $(\mathrm{~T})_{7}$ and $(\mathrm{A})_{7}$ & $(\mathrm{~A})_{9}$ \\
\hline Lolium perenne & $(\mathrm{A})_{10} \mathrm{G}(\mathrm{A})_{6}$ & $(\mathrm{~A})_{7} \mathrm{G}(\mathrm{A})_{6}$ & $(\mathrm{~T})_{8}$ & $(\mathrm{~T})_{9}$ and $(\mathrm{A})_{8}$ & $(\mathrm{~A})_{11}$ \\
\hline Sorghum nutans & $(\mathrm{A})_{9} \mathrm{G}(\mathrm{A})_{6}$ & $(\mathrm{~A})_{7} \mathrm{G}(\mathrm{A})_{10}$ & $(\mathrm{~T})_{8}$ & $(\mathrm{~T})_{10}$ and $(\mathrm{A})_{8}$ & $(\mathrm{~A})_{12}$ \\
\hline Streptochaeta angustifolia & $(\mathrm{A})_{8} \mathrm{G}(\mathrm{A})_{6}$ & $(\mathrm{~A})_{7} \mathrm{G}(\mathrm{A})_{9}$ & $(\mathrm{~T})_{8}$ & $(\mathrm{~T})_{7}$ and $(\mathrm{A})_{8}$ & $(\mathrm{~A})_{11}$ \\
\hline Zizania aquatica & $(\mathrm{A})_{8} \mathrm{G}(\mathrm{A})_{6}$ & $(\mathrm{~A})_{6} \mathrm{G}(\mathrm{A})_{6}$ & $(\mathrm{~T})_{8}$ & $(\mathrm{~T})_{9}$ and $(\mathrm{A})_{7}$ & $(\mathrm{~A})_{11}$ \\
\hline
\end{tabular}

halepense (Panicoideae), S. nutans (Panicoideae), Sporobolus gigantens (Chloridoideae), Streptochaeta angustifolia (Anomochlooideae), Thysanolaena maxima (Arundinoideae) and Zizania aquatica (Bambusoideae). Reactions were carried out on a thermal cycler (MWG Primus) using the following parameters: initial denaturation at $94{ }^{\circ} \mathrm{C}$ for $3 \mathrm{~min}$ followed by 35 cycles of denaturation at $94^{\circ} \mathrm{C}$ for $1 \mathrm{~min}$, annealing at $T_{\mathrm{m}}\left({ }^{\circ} \mathrm{C}\right)$ for $1 \mathrm{~min}$ (see Table 1 ) and extension at $72{ }^{\circ} \mathrm{C}$ for $1 \mathrm{~min}$ and a final extension at $72{ }^{\circ} \mathrm{C}$ for $5 \mathrm{~min}$. The PCR was carried out in a total volume of $10 \mu \mathrm{L}$ containing $2 \mu \mathrm{L}$ genomic DNA, 5 pmol 32P-end-labelled forward primer, 5 pmol reverse primer, $1 \times$ PCR reaction buffer [5 mm Tris- $\mathrm{HCl}, \mathrm{pH} 9.1,1.6 \mathrm{~mm}\left(\mathrm{NH}_{4}\right)_{2} \mathrm{SO}_{4}, 15 \mu \mathrm{g} / \mathrm{mL}$ bovine serum albumin], $2.5 \mathrm{~mm} \mathrm{MgCl}_{2}$ and $0.5 \mathrm{U} \mathrm{Taq}$ polymerase (Genetix). Products were resolved on a $6 \%$ denaturing polyacrylamide gel containing $1 \times$ TBE and $8 \mathrm{M}$ urea after the addition of $10 \mu \mathrm{L} \mathrm{95 \%} \mathrm{formamide} \mathrm{loading}$ buffer. Gels were run at $70 \mathrm{~W}$ constant power for $2 \mathrm{~h}$, transferred to blotting paper (3MM; Whatman) and exposed to $\mathrm{X}$-ray film for $1-2 \mathrm{~h}$ at $-20^{\circ} \mathrm{C}$. Each of the primer pairs amplified a product of the expected size in all of the species tested. Levels of interspecific variation were high, with between three ( $p s b \mathrm{~K}-p s b \mathrm{I})$ and $12(a t p \mathrm{~B}-r b c \mathrm{~L})$ alleles detected in the 16 species studied.

To confirm the conservation of a mononucleotide repeat across species, we sequenced one sample from each of the subfamilies used in the initial screen: B. gracilis (Chloridoideae), C. latifolium (Centothecoideae), D. spicata (Arundinoideae), L. perenne (Pooideae), S. nutans (Panicoideae), St. angustifolia (Anomochlooideae) and Zi. aquatica (Bambusoideae). The PCR was carried out using the cycling conditions described above in a total volume of $25 \mu \mathrm{L}$ containing $5 \mu \mathrm{L}$ genomic DNA, 5 pmol forward primer, 5 pmol reverse primer, $1 \times \mathrm{PCR}$ reaction buffer $[5 \mathrm{~mm}$ Tris- $\mathrm{HCl}$, $\mathrm{pH}$ 9.1, $1.6 \mathrm{~mm}\left(\mathrm{NH}_{4}\right)_{2} \mathrm{SO}_{4}, 15 \mu \mathrm{g} / \mathrm{mL}$ bovine serum albumin], $2.5 \mathrm{~mm} \mathrm{MgCl}_{2}$ and 0.5 U Taq polymerase (Genetix). Products were purified (QIAquick; Qiagen) and sequenced commercially. Sequencing of the amplified products confirmed that homologous repeats were present in all the taxa studied and that they were of sufficient length to potentially display intraspecific polymorphism (Table 2).

To test the potential of the primers to reveal intraspecific variation, they were used in a preliminary analysis of 25 accessions of Anthoxanthum odoratum (Avenae). Two of the 
loci were polymorphic, with two alleles at locus rpoC2/ $r p s 2$ and three alleles at locus $a t p \mathrm{~B} / r b c \mathrm{~L}$. Combining the data from these two loci gave three haplotypes and an overall Nei's haplotypic diversity value $(H)$ of 0.495 . The success of these primers in revealing intraspecific variation is in contrast to many of the studies that have used the 'universal' primers for all angiosperms (Weising \& Gardner 1999), where interruption of repeats across divergent taxa often leads to a lack of polymorphism (e.g. Rendell \& Ennos 2002). By restricting our scope to a narrower, but still widely studied range of taxa, we have successfully developed universal primers for high-resolution cytoplasmic analysis of grasses and cereals.

\section{Acknowledgements}

The authors would like to thank Jonathan Silvertown and Joanna Freeland for helpful discussions on Anthoxanthum. The
Anthoxanthum work was supported by NERC grant NER/B/S/ 2002/00266.

\section{References}

Provan J, Powell W, Dewar H, Bryan G, Machray GC, Waugh R (1999) An extreme cytoplasmic bottleneck in the modern European cultivated potato (Solanum tuberosum) is not reflected in decreased levels of nuclear diversity. Proceedings of the Royal Society of London B, 266, 633-639.

Provan J, Powell W, Hollingsworth PM (2001) Chloroplast microsatellites: new tools for studies in plant ecology and evolution. Trends in Ecology and Evolution, 16, 142-147.

Rendell A, Ennos RA (2002) Chloroplast DNA diversity in Calluna vulgaris (heather) populations in Europe. Molecular Ecology, 11, 69-78.

Weising K, Gardner RC (1999) A set of conserved PCR primers for the analysis of simple sequence repeat polymorphisms in the chloroplast genomes of dicotyledonous plants. Genome, 42, 9-19. 